\title{
Broncho-oesophageal fistula after lung cancer treatment
}

\author{
Hiroshi Sugimoto 지, ${ }^{1}$ Ayaka Yoshihara, ${ }^{1}$ Daisuke Obata, ${ }^{2}$ Keisuke Sugimoto ${ }^{1}$
}

${ }^{1}$ Department of Respiratory Medicine, Kobe Red Cross Hospital, Kobe, Hyogo, Japan ${ }^{2}$ Department of

Gastroenterology, Kobe Red Cross Hospital, Kobe, Hyogo, Japan

\section{Correspondence to} Dr Hiroshi Sugimoto; dr.sugimoto@gmail.com

Accepted 16 March 2020

\section{DESCRIPTION}

A 67-year-old Japanese man with locally advanced squamous cell lung cancer developed radiation pneumonitis after radical radiotherapy with concurrent carboplatin and paclitaxel followed by durvalumab. During the steroid treatment for radiation pneumonitis, he experienced a cough that worsened after drinking liquids.

Chest X-ray revealed the formation of a cavity in the mediastinum shadow and a chest CT scan also showed a cavity in the right lower lobe, where the lung cancer was originally located, and communicated with the bronchus intermedius (figure 1). Furthermore, the broncho-oesophageal fistula was diagnosed using oesophagography (figure 2).

Despite treatment, including an oesophageal stent for broncho-oesophageal fistula, he died of massive hemoptysis. We confirmed the cavity as the origin of bleeding following pathological autopsy.

Broncho-oesophageal fistula is defined as a communication between bronchus and oesophagus

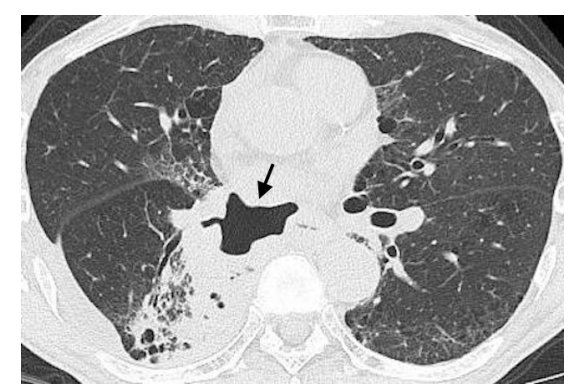

Figure 1 Axial CT shows a $4 \mathrm{~cm}$ cavitary lung lesion (arrow).

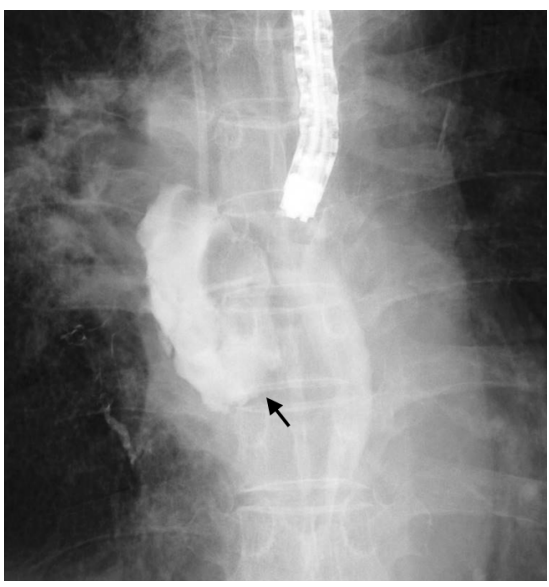

Figure 2 Oesophagography shows a bronchooesophageal fistula and a cavity in the right lower lobe (arrow).

\section{Learning points}

- For prompt diagnosis of broncho-oesophageal fistula, we clinicians should be attentive to the cough while eating or drinking in the patient after lung cancer treatment, especially radiotherapy.

- The multidisciplinary discussion is important to determine the appropriate treatment for broncho-oesophageal fistula.

and divided into congenital or acquired. The causes of acquired broncho-oesophageal fistula include malignancy, infections and trauma. ${ }^{1}$ In patients with malignancy, broncho-oesophageal fistula results from direct invasion of oesophageal or lung cancer or as a complication of cancer treatment, such as surgery, radiation, chemotherapy and instrumentation including oesophageal stents. ${ }^{2}$

The incidence of broncho-oesophageal fistula secondary to lung cancer is $0.3 \%$ and is relatively high after radiotherapy. ${ }^{3}$ Cough is the most common symptom of broncho-oesophageal fistula (56\%) and coughing while eating or drinking (Ono's sign) is typical. ${ }^{23}$ Although broncho-oesophageal fistula can be treated with surgery, oesophageal or bronchial stenting and endoscopic closure, most patients die of infection or bleeding within 3 months from onset. $^{3}{ }^{4}$ Furthermore, this patient had some risk factors for fatal hemoptysis such as squamous cell carcinoma and major cavitation. ${ }^{5}$

We should diagnose the broncho-oesophageal fistula promptly especially in the patient with squamous cell lung cancer after radiotherapy, then, determine the appropriate treatment for bronchooesophageal fistula via multidisciplinary discussion.

Contributors HS and AY drafted the manuscript. DO and KS reviewed and revised the manuscript.

Funding The authors have not declared a specific grant for this research from any funding agency in the public, commercial or not-for-profit sectors.

Competing interests None declared.

Patient consent for publication Next of kin consent obtained. Provenance and peer review Not commissioned; externally peer reviewed.

ORCID iD

Hiroshi Sugimoto http://orcid.org/0000-0002-2053-8858

\section{REFERENCES}

1 Aggarwal D, Mohapatra PR, Malhotra B. Acquired bronchoesophageal fistula. Lung India 2009;26:24-5. 
2 Reed MF, Mathisen DJ. Tracheoesophageal fistula. Chest Surg Clin N Am 2003;13:271-89.

3 Burt M, Diehl W, Martini N, et al. Malignant esophagorespiratory fistula: management options and survival. Ann Thorac Surg 1991;52:1222-9.

4 Zhou C, Hu Y, Xiao Y, et al. Current treatment of tracheoesophageal fistula. Ther Adv Respir Dis 2017;11:173-80.

Copyright 2020 BMJ Publishing Group. All rights reserved. For permission to reuse any of this content visit https://www.bmj.com/company/products-services/rights-and-licensing/permissions/

BMJ Case Report Fellows may re-use this article for personal use and teaching without any further permission.

Become a Fellow of BMJ Case Reports today and you can:

- Submit as many cases as you like

Enjoy fast sympathetic peer review and rapid publication of accepted articles

- Access all the published articles

Re-use any of the published material for personal use and teaching without further permission

Customer Service

If you have any further queries about your subscription, please contact our customer services team on +44 (0) 2071111105 or via email at support@bmj.com.

Visit casereports.bmj.com for more articles like this and to become a Fellow
5 Ito M, Niho S, Nihei K, et al. Risk factors associated with fatal pulmonary hemorrhage in locally advanced non-small cell lung cancer treated with chemoradiotherapy. BMC Cancer 2012;12:27. 